\title{
Bruton tyrosine kinase inhibitor ONO/GS-4059: from bench to bedside
}

\author{
Jingjing $\mathbf{W u}^{1}{ }$, Mingzhi Zhang ${ }^{1}$ and Delong Liu ${ }^{1}$ \\ ${ }^{1}$ Department of Oncology, The first Affiliated Hospital of Zhengzhou University, Zhengzhou, China \\ Correspondence to: Delong LiU, email: DELONG_LIU@NYMC.EDU \\ Keywords: Bruton tyrosine kinase, ONO/GS-4059, ibrutinib \\ Received: September 20,2016 Accepted: October 10,2016 Published: October 20, 2016
}

\begin{abstract}
The Bruton tyrosine kinase (BTK) inhibitor, ibrutinib, has been approved for the treatment of chronic lymphocytic leukemia, mantle cell lymphoma, and Waldenstrom's macroglobulinemia. Acquired resistance to ibrutinib due to BTK C481S mutation has been reported. Mutations in PLCY2 can also mediate resistance to ibrutinib. Untoward effects due to off-target effects are also disadvantages of ibrutinib. More selective and potent BTK inhibitors (ACP-196, ONO/GS-4059, BGB-3111, CC-292) are being investigated. This review summarized the preclinical research and clinical data of ONO/GS-4059.
\end{abstract}

\section{BACKGROUND}

A case report in 1952 by Mr. Bruton described a defect with complete absence of gamma globulin synthesis and later the defect was found to be X-linked [1-4]. The gene responsible for the disorder was independently isolated in 1993 by two different groups [5, 6]. The gene, now known as Bruton tyrosine kinase (BTK), is located on the $\mathrm{X}$ chromosome and encodes a polypeptide with 659 amino acid residues. BTK protein is now well known to be a downstream molecule of the B cell receptor (BCR) signaling pathway [7-9]. BTK plays a critical role in BCR signaling and B-cell development and function [10-13].

Targeted therapy against biomarker molecules has revolutionized drug development and cancer therapy [14-21]. Novel targeted agents have led to revolutions of lymphoma treatment [22-31]. Since BTK plays a critical role in B cell development and lymphomagenesis, BTK inhibitors have been in active clinical development [3236]. Early clinical studies have shown that targeting BTK in several B-cell malignancies have been highly effective with tolerable adverse effects [37-43]. The first-generation BTK inhibitor, ibrutinib (PCI-32765), has produced significant clinical response in patients with chronic lymphocytic leukemia (CLL), mantle cell lymphoma (MCL), diffuse large B cell lymphoma (DLBCL) [activated B cell (ABC)-like subtype] as well as in patients with Waldenstrom's macroglobulinemia (WM) [44-46]. Ibrutinib (imbruvica) has been approved for the treatment of CLL, MCL and WM [7, 34, 35, 40,
44-50]. However, there are adverse events like bleeding, rash, atrial fibrillation reported, which were thought to be mostly associated with the off-target effects of ibrutinib $[40,48,51-58]$. Emerging resistance to ibrutinib was also reported $[59,60]$. BTK C481S and T316A mutations lead to ibrutinib resistance [61, 62]. Mutations in PLC $\gamma 2$ can also mediate resistance to ibrutinib. Therefore, more selective and specific BTK inhibitors, such as ACP-196 (acalabrutinib), ONO/GS-4059, BGB-3111, are being explored and developed $[20,33,34,36,61,63]$. In this review we summarized the preclinical research and clinical development of ONO/GS-4059.

\section{MECHANISM OF ACTIONS AND PROPERTIES OF ONO/GS-4059}

ONO/GS-4059 (formerly known as ONOWG-307) is a highly potent and selective BTK inhibitor [64, 65]. This molecule can inhibit BTK by blocking auto-phosphorylation at the Tyr223 position. Through quantitative phosphoproteomics analysis of phosphorylated BTK proteins by mass spectrometry followed by bio-informatic processing, site-specific phosphorylations were identified [65]. BTK protein was found to be potently and selectively inhibited by $\mathrm{ONO} /$ GS-4059 (ONO-WG-307). The $\mathrm{IC}_{50}$ of ONO/GS-4059 was in the sub-nanomolar range, which was much lower than the $\mathrm{IC}_{50}$ values (above $1 \mu \mathrm{M}$ ) for other tyrosine kinases (Lck, Lyn and Fyn). This suggests that ONO/GS-4059 is highly specific for BTK. In comparison with ibrutinib, 


\section{Ibrutinib ONO/GS-4059}

\begin{tabular}{lll}
\hline Target & BTK & BTK \\
off-target effects & ++ & $+^{*}$ \\
AC in trials & Not allowed & allowed \\
Platelet inhibition & yes & NA \\
Atrial Fibrillation & observed & observed \\
Approved indications & CLL/SLL, & none \\
& MCL,WM &
\end{tabular}

Abbreviations: BTK: Bruton tyrosine kinase; AC: anticoagulation; NA: not available /reported; CLL: chronic lymphoid leukemia; SLL: small lymphoid leukemia; MCL: mantle cell lymphoma; WM: Waldenstrom's macroglobulinemia. *: off-target effects were seen in vitro, but overall weaker than those seen with ibrutinib; ${ }^{* *}$ : the atrial fibrillation was not thought to be drug- related

ONO/GS-4059 has less bleeding risks (table 1).

ONO/GS-4059 inhibits BTK signaling through AKT and protein kinase D $[65,66]$. ONO/GS-4059 exhibits significant activity in vivo in the ABC-DLBCL TMD8 xenograft model, in vitro anti-proliferative effects in DLBCL, FL, MCL and CLL cell lines and its combination with other targeted agents [64-68].

\section{ONO/GS-4059 IN PRECLINICAL RESEARCH}

ONO/GS-4059 (formerly known as ONO-WG-307) was initially evaluated in cells and in the mouse models [64-68]. In the initial in vitro study, ONO-WG-307 alone and in combination with rituximab were tested in FL and ABC-DLBCL cell lines [64]. The same cells were also used to explore ONO-WG-307 anti-tumor activity in a mouse model. The DLBCL cells were much more sensitive than FL cell lines to single agent OPN-WG-307. In fact, when ONO-WG-307 was combined with rituximab, antagonism of a modest degree was observed in the FL cell lines. Treatment with single agent ONO-WG-307 showed anti-tumor activity in the xenograft models.

The inhibitory effect of ONO/GS-4059 on BTKdependent signal transduction was further investigated in two tumor cell lines (sensitive and non-sensitive) [65]. The $\mathrm{IC}_{50}$ of BTK inhibition in the sensitive cells was $3.59 \mathrm{nmol} / \mathrm{L}$. The inhibition of cellular BTK and ERK phosphorylation were similar in both sensitive and nonsensitive cells. These data demonstrated that the selective inhibition of cell growth by ONO/GS-4059 was due to blocking of BTK-mediated signaling through AKT and cellular protein kinase D.

ONO/GS-4059 was further analyzed in vivo for its effects on gene expressions in a xenograft model of the ABC-DLBCL cell line (TMD-8) [66]. ONO/GS-4059 was shown to affect the expression of a core set of genes in a dose-dependent manner. This study confirmed the profound anti-proliferative activity of ONO/GS-4059 by inhibiting BTK in the TMD-8 mouse model.

ONO/GS-4059 was also evaluated in combination with other agents. Combination of idelalisib, a phophotidylinositol 3 kinase (PI3K) inhibitor [69], showed synergistic activity in inhibiting the growth of a subset of DLBCL and MCL cell lines, including 3 ABC-DLBCL cell lines (OCI-LY10, Ri-1, and TMD8) and 2 MCL cell lines (Rec-1 and JMV-2) [67]. Two mechanisms of resistance to BTK inhibitors were identified in the TMD8 cell line: a NF-kB inhibitor A20 mutation (TNFAIP3 Q143*), and a BTK mutation (C481F). TMD8 cells with A20 mutant were sensitive to the combination with $\mathrm{ONO} /$ GS-4059 as well as the idelalisib alone. The BTK-C481F mutated TMD8 cells were less sensitive to the idelalisib single agent and addition of ONO/GS-4059 did not enhance the inhibitory activity. In a separate report, TMD8 cells were exposed to high dose idelalisib to establish a resistant cell line [70]. The cell line was resistant not only to idelalisib, but also to both ibrutinib and ONO/GS-4059, confirming that BTK-mediated signaling pathway plays a major role in the B cell survival. These data suggest that combination therapy may be better to overcome resistance in the BTK signaling pathway through the inhibition of PI3 kinase by idelalisib. Quadruple combinations of the $\mathrm{B}$ cell receptor pathway inhibitors, entospletinib, ONO/ GS-4059, idelalisib, and ABT-199 were studied in vitro in primary CLL cells $[15,71,72]$. The study showed that combination treatment synergistically increased the apoptosis in primary CLL cells compared to the individual agents and achieved the maximal levels of apoptosis.

\section{ONO/GS-4059 IN CLINICAL DEVELOPMENT}

The first-in-human phase I study of ONO/GS-4059 was ongoing in relapsed/refractory B-cell malignancies (NCT01659255) [63, 73-75]. In the last update, 90 
patients were evaluable for the efficacy and safety. The patients had a spectrum of $B$ cell malignancies (CLL $\mathrm{n}=28$, MCL n=16, DLBCL n=35, FL n=5, WM n=3, MZL $\mathrm{n}=2$ and SLL $\mathrm{n}=1$ ). The study was safety-driven, doseescalating in a $3+3$ design. The cohorts ranged from $20 \mathrm{mg}$ to $600 \mathrm{mg}$ once daily with twice-daily regimens of $240 \mathrm{mg}$ and $300 \mathrm{mg}$. In the CLL group, 96\% (24/25) patients have gained objective response within the first 3 months of therapy. Rapid responses in the lymph nodes were seen in those with concurrent lymphocytosis. High overall response rates were reported in the CLL (96\%, 24/25 patients) and in the MCL group (92\%, 11/12 patients). Much lower response rate was seen in the patients with non-germinal center DLBCL $(35 \%, 11 / 31)$. Therefore, responses of DLBCL were much lower and less durable with most patients dying from disease progression. It was particularly remarkable that those CLL and MCL patients with chromosome $17 \mathrm{p}$ deletion and/or TP53 mutation or following allogeneic stem cell transplantation responded rapidly. Rapid absorption and elimination were noted, with a half-life of 6.5 to 8 hours for the BTK inhibitor. ONO/ GS-4059 was well tolerated with no maximal tolerated dosage (MTD) reached in the CLL group at the last update. In the lymphoma cohort, $480 \mathrm{mg}$ once daily was the MTD. Most adverse events (AE) were grade 1 or 2 . Severe AEs were seen mainly with hematologic toxicities, which were transient and recovered spontaneously [63]. In this trial, anticoagulation was allowed, whereas in ibrutinib trials, anticoagulation was not. Increased bleeding was not observed in this report in the 28 patients who were on anticoagulation. From the early phase studies, the BTK inhibitor ONO/GS-4059 appears to have a favorable safety profile in patients with relapsed/refractory B-cell malignancies. Its high response rates in poor risk patients with CLL and MCL are particularly remarkable.

\section{CONCLUSION AND FUTURE DIRECTIONS}

ONO/GS-4059 is a novel, potent and selective second-generation inhibitor of BTK. It can inhibit autophosphorylation of the BTK at the Tyr223 position through the ERK, AKT and PKD signaling pathways. This drug exhibits significant antitumor activity in preclinical models and in phase I clinical trials. To date, the efficacy and tolerability of ibrutinib have led the way to further development of novel agents in the treatment of B cell malignancies. New generation BTK inhibitors have improved selectivity and efficacy, however, they are still in early stage of clinical trials. In addition, acquired resistance to the BTK inhibitors have been reported. With the rapid clinical development of novel agents of bispecific antibodies [76-78], antibody-drug conjugates [79, 80], immune checkpoint blockers [81-83], and CAR-T for cancer immunotherapies [84-87], combinations of BTK inhibitors with novel agents may overcome acquired resistance in refractory B cell malignancies [88].

\section{Abbreviations}

BTK: Bruton tyrosine kinase; ORR: overall response rate; PR: partial response; SD: stable disease; DLT: doselimiting toxicity; MTD: maximal tolerated dose.

\section{ACKNOWLEDGMENTS}

Jingjing $\mathrm{Wu}$ is a recipient of the Henan Provincial Grant for Overseas Research for Young Leaders of Medical Technology (No. 2014041). She also received grant support from the Natural Science Foundation of China (NSFC No. 81201793). The grants supported her research training at the Division of Hematology and Oncology, New York Medical College and Westchester Medical Center, Valhalla, NY, USA.

\section{CONFLICTS OF INTERESTS}

The authors have no relevant conflicts.

\section{Author contributions}

DL designed the study. JW and DL drafted the manuscript. MZ provided helpful suggestions. All authors read and approved the final manuscript.

\section{REFERENCES}

1. Bruton OC. Agammaglobulinemia. Pediatrics. 1952; 9(6):722-728.

2. Vetrie D. Isolation of the defective gene in $\mathrm{X}$ linked agammaglobulinaemia. J Med Genet. 1993; 30(6):452-453.

3. Maas A and Hendriks RW. Role of Bruton's tyrosine kinase in B cell development. Dev Immunol. 2001; 8(3-4):171181.

4. Valiaho J, Smith CI and Vihinen M. BTKbase: the mutation database for X-linked agammaglobulinemia. Hum Mutat. 2006; 27(12):1209-1217.

5. Tsukada S, Saffran DC, Rawlings DJ, Parolini O, Allen RC, Klisak I, Sparkes RS, Kubagawa H, Mohandas T, Quan $\mathrm{S}$ and et al. Deficient expression of a B cell cytoplasmic tyrosine kinase in human X-linked agammaglobulinemia. Cell. 1993; 72(2):279-290.

6. Vetrie D, Vorechovsky I, Sideras P, Holland J, Davies A, Flinter F, Hammarstrom L, Kinnon C, Levinsky R, Bobrow $\mathrm{M}$ and et al. The gene involved in $\mathrm{X}$-linked agammaglobulinaemia is a member of the src family of protein-tyrosine kinases. Nature. 1993; 361(6409):226-233.

7. Novero A, Ravella PM, Chen Y, Dous G and Liu D. Ibrutinib for B cell malignancies. Exp Hematol Oncol. 2014; 3:4.

8. Tai YT, Chang BY, Kong SY, Fulciniti M, Yang G, Calle 
Y, Hu Y, Lin J, Zhao JJ, Cagnetta A, Cea M, Sellitto MA, Zhong MY, Wang Q, Acharya C, Carrasco DR, et al. Bruton tyrosine kinase inhibition is a novel therapeutic strategy targeting tumor in the bone marrow microenvironment in multiple myeloma. Blood. 2012; 120(9):1877-1887.

9. Yang Y, Shi J, Gu Z, Salama ME, Das S, Wendlandt E, $\mathrm{Xu} \mathrm{H}$, Huang J, Tao Y, Hao M, Franqui R, Levasseur D, Janz S, Tricot G and Zhan F. Bruton. Tyrosine kinase is a therapeutic target in stem-like cells from multiple myeloma. Cancer Res. 2015; 75(3):594-604.

10. Herman SE, Gordon AL, Hertlein E, Ramanunni A, Zhang X, Jaglowski S, Flynn J, Jones J, Blum KA, Buggy JJ, Hamdy A, Johnson AJ and Byrd JC. Bruton tyrosine kinase represents a promising therapeutic target for treatment of chronic lymphocytic leukemia and is effectively targeted by PCI-32765. Blood. 2011; 117(23):6287-6296.

11. Liu J, Fitzgerald ME, Berndt MC, Jackson CW and Gartner TK. Bruton tyrosine kinase is essential for botrocetin/VWFinduced signaling and GPIb-dependent thrombus formation in vivo. Blood. 2006; 108(8):2596-2603.

12. Wang K, Wei G and Liu D. CD19: a biomarker for B cell development, lymphoma diagnosis and therapy. Exp Hematol Oncol. 2012; 1(1):36.

13. Yu L, Mohamed AJ, Vargas L, Berglof A, Finn G, Lu $\mathrm{KP}$ and Smith CI. Regulation of Bruton tyrosine kinase by the peptidylprolyl isomerase Pin1. J Biol Chem. 2006; 281(26):18201-18207.

14. Smith A, Roda D and Yap T. Strategies for modern biomarker and drug development in oncology. J Hematol Oncol. 2014; 7:70.

15. Cang S, Iragavarapu C, Savooji J, Song Y and Liu D. ABT-199 (venetoclax) and BCL-2 inhibitors in clinical development. J Hematol Oncol. 2015; 8(1):129.

16. Das A, Wei G, Parikh K and Liu D. Selective inhibitors of nuclear export (SINE) in hematological malignancies. Exp Hematol Oncol. 2015; 4(1):1-4.

17. Goede V, Fischer K, Busch R, Engelke A, Eichhorst B, Wendtner CM, Chagorova T, de la Serna J, Dilhuydy MS, Illmer T, Opat S, Owen CJ, Samoylova O, Kreuzer KA, Stilgenbauer S, Dohner H, et al. Obinutuzumab plus chlorambucil in patients with CLL and coexisting conditions. N Engl J Med. 2014; 370(12):1101-1110.

18. Iragavarapu C, Mustafa M, Akinleye A, Furqan M, Mittal V, Cang S and Liu D. Novel ALK inhibitors in clinical use and development. J Hematol Oncol.. 2015; 8(1):17.

19. Parikh K, Cang S, Sekhri A and Liu D. Selective inhibitors of nuclear export (SINE)- a novel class of anti-cancer agents. J Hematol Oncol.. 2014; 7(1):78.

20. Tam C, Grigg AP, Opat S, Ku M, Gilbertson M, Anderson MA, Seymour JF, Ritchie DS, Dicorleto C, Dimovski B, Hedrick E, Yang J, Wang L, Luo L, Xue L and Roberts AW. The BTK Inhibitor, Bgb-3111, Is Safe, Tolerable, and Highly Active in Patients with Relapsed/ Refractory B-Cell Malignancies: Initial Report of a Phase 1 First-in-Human
Trial. Blood. 2015; 126(23):832.

21. Kim A, Seong KM, Kang HJ, Park S and Lee SS. Inhibition of Lyn is a promising treatment for mantle cell lymphoma with bortezomib resistance. Oncotarget. 2015; 6:3822538238. doi: 10.18632/oncotarget.5425.

22. Breton C, Nahimana A, Aubry D, Macoin J, Moretti P, Bertschinger M, Hou S, Duchosal M and Back J. A novel anti-CD19 monoclonal antibody (GBR 401) with high killing activity against $\mathrm{B}$ cell malignancies. J Hematol Oncol. 2014; 7(1):33.

23. Rai KR and Barrientos JC. Movement toward optimization of CLL therapy. N Engl J Med. 2014; 370(12):1160-1162.

24. Reusch U, Burkhardt C, Fucek I, Le Gall F, Le Gall M, Hoffmann K, Knackmuss SH, Kiprijanov S, Little M and Zhukovsky EA. A novel tetravalent bispecific TandAb (CD30/CD16A) efficiently recruits NK cells for the lysis of CD30+ tumor cells. mAbs. 2014; 6(3):728-739.

25. Reusch U, Duell J, Ellwanger K, Herbrecht C, Knackmuss SH, Fucek I, Eser M, McAleese F, Molkenthin V, Gall FL, Topp M, Little M and Zhukovsky EA. A tetravalent bispecific TandAb (CD19/CD3), AFM11, efficiently recruits $\mathrm{T}$ cells for the potent lysis of CD19(+) tumor cells. mAbs. 2015; 7(3):584-604.

26. Suresh T, Lee L, Joshi J and Barta S. New antibody approaches to lymphoma therapy. J Hematol Oncol. 2014; 7(1):58.

27. Wu J, Fu J, Zhang M and Liu D. AFM13: a first-in-class tetravalent bispecific anti-CD30/CD16A antibody for NK cell-mediated immunotherapy. J Hematol Oncol. 2015; 8:96.

28. Wu J, Fu J, Zhang M and Liu D. Blinatumomab: a bispecific $T$ cell engager (BiTE) antibody against CD19/CD3 for refractory acute lymphoid leukemia. J Hematol Oncol. 2015; 8:104.

29. Camicia R, Winkler HC and Hassa PO. Novel drug targets for personalized precision medicine in relapsed/refractory diffuse large B-cell lymphoma: a comprehensive review. Molecular Cancer. 2015; 14:207.

30. Ma J, Xing W, Coffey G, Dresser K, Lu K, Guo A, Raca G, Pandey A, Conley P, Yu H and Wang YL. Cerdulatinib, a novel dual SYK/JAK kinase inhibitor, has broad antitumor activity in both $\mathrm{ABC}$ and GCB types of diffuse large B cell lymphoma. Oncotarget. 2015; 6:43881-43896. doi: 10.18632/oncotarget.6316.

31. Lee JS, Tang SS, Ortiz V, Vo TT and Fruman DA. MCL1-independent mechanisms of synergy between dual $\mathrm{PI} 3 \mathrm{~K} / \mathrm{mTOR}$ and BCL-2 inhibition in diffuse large B cell lymphoma. Oncotarget. 2015; 6:35202-35217. doi: 10.18632/oncotarget.6051.

32. Novero A, Ravella PM, Chen Y, Dous G and Liu D. Ibrutinib for B cell malignancies. Exp Hematol Oncol. 2014; 3(1):4.

33. Wu J, Zhang M and Liu D. Acalabrutinib (ACP-196): a selective second-generation BTK inhibitor. J Hematol 
Oncol. 2016; 9(1):21.

34. Aalipour A and Advani RH. Bruton tyrosine kinase inhibitors: a promising novel targeted treatment for B cell lymphomas. Br J Haematol. 2013; 163(4):436-443.

35. Advani RH, Buggy JJ, Sharman JP, Smith SM, Boyd TE, Grant B, Kolibaba KS, Furman RR, Rodriguez S, Chang BY, Sukbuntherng J, Izumi R, Hamdy A, Hedrick E and Fowler NH. Bruton tyrosine kinase inhibitor ibrutinib (PCI32765) has significant activity in patients with relapsed/ refractory B-cell malignancies. J Clin Oncol. 2013; 31(1):88-94.

36. Byrd JC, Harrington B, O'Brien S, Jones JA, Schuh A, Devereux S, Chaves J, Wierda WG, Awan FT, Brown JR, Hillmen P, Stephens DM, Ghia P, Barrientos JC, Pagel JM, Woyach J, et al. Acalabrutinib (ACP-196) in Relapsed Chronic Lymphocytic Leukemia. N Engl J Med. 2016; 374(4):323-332.

37. Buggy JJ and Elias L. Bruton tyrosine kinase (BTK) and its role in B-cell malignancy. Int Rev Immunol. 2012; 31(2):119-132.

38. Burger JA. Bruton's tyrosine kinase (BTK) inhibitors in clinical trials. Curr Hematol Malig Rep. 2014; 9(1):44-49.

39. Burger JA and Buggy JJ. Bruton tyrosine kinase inhibitor ibrutinib (PCI-32765). Leuk Lymphoma. 2013; 54(11):2385-2391.

40. Burger JA, Tedeschi A, Barr PM, Robak T, Owen C, Ghia P, Bairey O, Hillmen P, Bartlett NL, Li J, Simpson D, Grosicki S, Devereux S, McCarthy H, Coutre S, Quach $\mathrm{H}$, et al. Ibrutinib as Initial Therapy for Patients with Chronic Lymphocytic Leukemia. N Engl J Med. 2015; 373(25):2425-2437.

41. Honigberg LA, Smith AM, Sirisawad M, Verner E, Loury D, Chang B, Li S, Pan Z, Thamm DH, Miller RA and Buggy JJ. The Bruton tyrosine kinase inhibitor PCI-32765 blocks B-cell activation and is efficacious in models of autoimmune disease and B-cell malignancy. Proc Natl Acad Sci U S A. 2010; 107(29):13075-13080.

42. Pan Z, Scheerens H, Li SJ, Schultz BE, Sprengeler PA, Burrill LC, Mendonca RV, Sweeney MD, Scott KC, Grothaus PG, Jeffery DA, Spoerke JM, Honigberg LA, Young PR, Dalrymple SA and Palmer JT. Discovery of selective irreversible inhibitors for Bruton's tyrosine kinase. ChemMedChem. 2007; 2(1):58-61.

43. Rai KR. Therapeutic potential of new B cell-targeted agents in the treatment of elderly and unfit patients with chronic lymphocytic leukemia. J Hematol Oncol. 2015; 8:85.

44. Byrd JC, Furman RR, Coutre SE, Flinn IW, Burger JA, Blum KA, Grant B, Sharman JP, Coleman M, Wierda WG, Jones JA, Zhao W, Heerema NA, Johnson AJ, Sukbuntherng J, Chang BY, et al. Targeting BTK with ibrutinib in relapsed chronic lymphocytic leukemia. N Engl J Med. 2013; 369(1):32-42.

45. Treon SP, Xu L and Hunter Z. MYD88 Mutations and Response to Ibrutinib in Waldenstrom's
Macroglobulinemia. N Engl J Med. 2015; 373(6):584-586.

46. Wang ML, Rule S, Martin P, Goy A, Auer R, Kahl BS, Jurczak W, Advani RH, Romaguera JE, Williams ME, Barrientos JC, Chmielowska E, Radford J, Stilgenbauer S, Dreyling M, Jedrzejczak WW, et al. Targeting BTK with ibrutinib in relapsed or refractory mantle-cell lymphoma. N Engl J Med. 2013; 369(6):507-516.

47. Broides A, Hadad N, Levy J and Levy R. The effects of Bruton tyrosine kinase inhibition on chemotaxis and superoxide generation in human neutrophils. J Clin Immunol. 2014; 34(5):555-560.

48. Byrd JC, Brown JR, O’Brien S, Barrientos JC, Kay NE, Reddy NM, Coutre S, Tam CS, Mulligan SP, Jaeger U, Devereux S, Barr PM, Furman RR, Kipps TJ, Cymbalista F, Pocock $\mathrm{C}$, et al. Ibrutinib versus ofatumumab in previously treated chronic lymphoid leukemia. N Engl J Med. 2014; 371(3):213-223.

49. Castillo JJ, Treon SP and Davids MS. Inhibition of the Bruton Tyrosine Kinase Pathway in B-Cell Lymphoproliferative Disorders. Cancer J. 2016; 22(1):3439.

50. Treon SP, Tripsas CK, Meid K, Warren D, Varma G, Green R, Argyropoulos KV, Yang G, Cao Y, Xu L, Patterson CJ, Rodig S, Zehnder JL, Aster JC, Harris NL, Kanan $\mathrm{S}$, et al. Ibrutinib in previously treated Waldenstrom's macroglobulinemia. N Engl J Med. 2015; 372(15):14301440 .

51. Byrd JC, Furman RR, Coutre SE, Burger JA, Blum KA, Coleman M, Wierda WG, Jones JA, Zhao W, Heerema NA, Johnson AJ, Shaw Y, Bilotti E, Zhou C, James DF and O'Brien S. Three-year follow-up of treatment-naive and previously treated patients with CLL and SLL receiving single-agent ibrutinib. Blood. 2015; 125(16):2497-2506.

52. Cheng G, Ye ZS and Baltimore D. Binding of Bruton's tyrosine kinase to Fyn, Lyn, or Hck through a Src homology 3 domain-mediated interaction. Proc Natl Acad Sci U S A. 1994; 91(17):8152-8155.

53. Fabbro SK, Smith SM, Dubovsky JA, Gru AA and Jones JA. Panniculitis in Patients Undergoing Treatment With the Bruton Tyrosine Kinase Inhibitor Ibrutinib for Lymphoid Leukemias. JAMA Oncol. 2015; 1(5):684-686.

54. Levade M, David E, Garcia C, Laurent PA, Cadot S, Michallet AS, Bordet JC, Tam C, Sie P, Ysebaert L and Payrastre B. Ibrutinib treatment affects collagen and von Willebrand factor-dependent platelet functions. Blood. 2014; 124(26):3991-3995.

55. Matsuda T, Takahashi-Tezuka M, Fukada T, Okuyama Y, Fujitani Y, Tsukada S, Mano H, Hirai H, Witte ON and Hirano T. Association and activation of Btk and Tec tyrosine kinases by gp130, a signal transducer of the interleukin-6 family of cytokines. Blood. 1995; 85(3):627633.

56. McMullen JR, Boey EJ, Ooi JY, Seymour JF, Keating $\mathrm{MJ}$ and Tam CS. Ibrutinib increases the risk of atrial 
fibrillation, potentially through inhibition of cardiac PI3KAkt signaling. Blood. 2014; 124(25):3829-3830.

57. Schwartzberg PL, Finkelstein LD and Readinger JA. TECfamily kinases: regulators of T-helper-cell differentiation. Nat Rev Immunol. 2005; 5(4):284-295.

58. Seiter K, Stiefel MF, Barrientos J, Shaikh A, Ahmed N, Baskind P and Liu D. Successful treatment of ibrutinibassociated central nervous system hemorrhage with platelet transfusion support. Stem Cell Investigation. 2016; 3:27.

59. Woyach JA, Furman RR, Liu TM, Ozer HG, Zapatka M, Ruppert AS, Xue L, Li DH, Steggerda SM, Versele M, Dave SS, Zhang J, Yilmaz AS, Jaglowski SM, Blum KA, Lozanski A, et al. Resistance mechanisms for the Bruton's tyrosine kinase inhibitor ibrutinib. N Engl J Med. 2014; 370(24):2286-2294.

60. Furman RR, Cheng S, Lu P, Setty M, Perez AR, Guo A, Racchumi J, Xu G, Wu H, Ma J, Steggerda SM, Coleman $\mathrm{M}$, Leslie $\mathrm{C}$ and Wang YL. Ibrutinib resistance in chronic lymphocytic leukemia. N Engl J Med. 2014; 370(24):23522354.

61. Wu J, Liu C, Tsui ST and Liu D. Second-generation inhibitors of Bruton tyrosine kinase. J Hematol Oncol. 2016; 9:80.

62. Sharma S, Galanina N, Guo A, Lee J, Kadri S, Van Slambrouck C, Long B, Wang W, Ming M, Furtado LV, Segal JP, Stock W, Venkataraman G, Tang WJ, Lu P and Wang YL. Identification of a structurally novel BTK mutation that drives ibrutinib resistance in CLL. Oncotarget. 2016; 7:68833-68841. doi: 10.18632/oncotarget.11932.

63. Walter HS, Rule SA, Dyer MJ, Karlin L, Jones C, Cazin B, Quittet P, Shah N, Hutchinson CV, Honda H, Duffy K, Birkett J, Jamieson V, Courtenay-Luck N, Yoshizawa T, Sharpe J, et al. A phase 1 clinical trial of the selective BTK inhibitor ONO/GS-4059 in relapsed and refractory mature B-cell malignancies. Blood. 2016; 127(4):411-419.

64. Kozaki R, Yoshizawa T, Yasuhiro T, Mirjolet J-F, Birkett J, Narita M and Kawabata K. Abstract 857: Development of a Bruton's tyrosine kinase (Btk) inhibitor - ONO-WG-307, a potential treatment for B-cell malignancies. Cancer Research. 2012; 72(8 Supplement):857-857.

65. Yasuhiro T, Yoshizawa T, Daub H, Weber C, Narita M and Kawabata K. Abstract 2021: ONO-WG-307, a novel, potent and selective inhibitor of Bruton's tyrosine kinase (Btk), results in sustained inhibition of the ERK, AKT and PKD signaling pathways. Cancer Research. 2012; 72(8 Supplement):2021-2021.

66. Yasuhiro T, Yoshizawa T, Hotta S, Ariza Y, Ueda Y, Kozaki $\mathrm{R}$ and Birkett J. Abstract 2452: ONO-4059, a novel oral Bruton's tyrosine kinase (Btk) inhibitor that demonstrates potent pharmacodynamic activity through Phosphorylated Btk (P-Btk) inhibition, in addition to effective anti-tumour activity in a TMD-8 (DLBCL) xenograft model. Cancer Research. 2013; 73(8 Supplement):2452.

67. Tannheimer S, Liu J, Sorensen R, Yahiaoui A, Meadows S,
Li L, Yue P, Keegan KS, Bates J, Tumas D and Queva C. Combination of Idelalisib and ONO/GS-4059 in Lymphoma Cell Lines Sensitive and Resistant to BTK Inhibitors. Blood. 2015; 126(23):3697-3697.

68. Jones R, Axelrod MJ, Tumas D, Quéva C and Di Paolo J. Combination Effects of B Cell Receptor Pathway Inhibitors (Entospletinib, ONO/GS-4059, and Idelalisib) and a BCL-2 Inhibitor in Primary CLL Cells. Blood. 2015; 126(23):17491749.

69. Pandey R and Kapur R. Targeting phosphatidylinositol-3kinase pathway for the treatment of Philadelphia-negative myeloproliferative neoplasms. Molecular Cancer. 2015; 14:118.

70. Meadows S, Rick S, Anella Y, Liu J, Li L, Yue P, Queva $\mathrm{C}$ and Tannheimer S. Up-Regulation of the PI3K Signaling Pathway Mediates Resistance to Idelalisib. Blood. 2015; 126(23):3707-3707.

71. Akinleye A, Avvaru P, Furqan M, Song Y and Liu D. Phosphatidylinositol 3-kinase (PI3K) inhibitors as cancer therapeutics. J Hematol Oncol. 2013; 6:88.

72. Sharman J, Hawkins M, Kolibaba K, Boxer M, Klein L, Wu $\mathrm{M}, \mathrm{Hu}$ J, Abella S and Yasenchak C. An open-label phase 2 trial of entospletinib (GS-9973), a selective spleen tyrosine kinase inhibitor, in chronic lymphocytic leukemia. Blood. 2015; 125(15):2336-2343.

73. Dyer M HC, Rule S, et al. Abstract 8553: The Bruton's tyrosine kinase (BTK) inhibitor ONO-4059: Single-agent activity in patients with relapsed and refractory non-GCBDLBCL. J Clin Oncol. 2014; 32:suppl; abstr 8553.

74. Rule S SN, Salles G, et al. Abstract 4397: A Phase I Study Of The Oral Btk Inhibitor ONO-4059 In Patients With Relapsed/Refractory B-Cell Lymphoma. Blood. 2013; 122(21):Abstract \#4397.

75. Salles G KL, Rule S, et al. Abstract 676: A Phase I Study Of The Oral Btk Inhibitor ONO-4059 In Patients With Relapsed/Refractory and High Risk Chronic Lymphocytic Leukaemia (CLL). Blood. 2013; 122(21):Abstract \#676.

76. Topp MS, Gokbuget N, Stein AS, Zugmaier G, O'Brien S, Bargou RC, Dombret H, Fielding AK, Heffner L, Larson RA, Neumann S, Foa R, Litzow M, Ribera JM, Rambaldi A, Schiller G, et al. Safety and activity of blinatumomab for adult patients with relapsed or refractory B-precursor acute lymphoblastic leukaemia: a multicentre, single-arm, phase 2 study. Lancet Oncol. 2014; 16(1):57-66.

77. Topp MS, Gokbuget N, Zugmaier G, Degenhard E, Goebeler ME, Klinger M, Neumann SA, Horst HA, Raff T, Viardot A, Stelljes M, Schaich M, Kohne-Volland R, Bruggemann M, Ottmann OG, Burmeister T, et al. Longterm follow-up of hematologic relapse-free survival in a phase 2 study of blinatumomab in patients with MRD in B-lineage ALL. Blood. 2012; 120(26):5185-5187.

78. Fan G, Wang Z, Hao M and Li J. Bispecific antibodies and their applications. J Hematol Oncol. 2015; 8:130.

79. Rael E, Rakszawski K, Koller K, Bayerl M, Butte M and 
Zheng H. Treatment with rituximab and brentuximab vedotin in a patient of common variable immune deficiencyassociated classic Hodgkin lymphoma. Biomarker Research. 2016; 4:7.

80. Bartlett NL, Chen R, Fanale MA, Brice P, Gopal A, Smith SE, Advani R, Matous JV, Ramchandren R, Rosenblatt JD, Huebner D, Levine P, Grove L and Forero-Torres A. Retreatment with brentuximab vedotin in patients with CD30-positive hematologic malignancies. J Hematol Oncol. 2014; 7:24.

81. Brahmer JR, Tykodi SS, Chow LQ, Hwu WJ, Topalian SL, Hwu P, Drake CG, Camacho LH, Kauh J, Odunsi K, Pitot HC, Hamid O, Bhatia S, Martins R, Eaton K, Chen S, et al. Safety and activity of anti-PD-L1 antibody in patients with advanced cancer. N Engl J Med. 2012; 366(26):2455-2465.

82. Curran MA, Montalvo W, Yagita H and Allison JP. PD-1 and CTLA-4 combination blockade expands infiltrating $\mathrm{T}$ cells and reduces regulatory $\mathrm{T}$ and myeloid cells within B16 melanoma tumors. Proc Natl Acad Sci U S A. 2010; 107(9):4275-4280.

83. Tsai K and Daud A. Nivolumab plus ipilimumab in the treatment of advanced melanoma. J Hematol Oncol. 2015; 8(1): 123 .

84. Qin H, Cho M, Haso W, Zhang L, Tasian SK, Oo HZ, Negri GL, Lin Y, Zou J, Mallon BS, Maude S, Teachey DT, Barrett DM, Orentas RJ, Daugaard M, Sorensen PH, et al. Eradication of B-ALL using chimeric antigen receptorexpressing T cells targeting the TSLPR oncoprotein. Blood. 2015; 126(5):629-639.
85. Maude SL, Frey N, Shaw PA, Aplenc R, Barrett DM, Bunin NJ, Chew A, Gonzalez VE, Zheng Z, Lacey SF, Mahnke YD, Melenhorst JJ, Rheingold SR, Shen A, Teachey DT, Levine BL, et al. Chimeric antigen receptor $\mathrm{T}$ cells for sustained remissions in leukemia. N Engl J Med. 2014; 371(16):1507-1517.

86. Zhukovsky EA, Morse RJ and Maus MV. Bispecific antibodies and CARs: generalized immunotherapeutics harnessing T cell redirection. Curr Opin Immunol. 2016; 40:24-35.

87. Shi H, Sun M, Liu L and Wang Z. Chimeric antigen receptor for adoptive immunotherapy of cancer: latest research and future prospects. Mol Cancer. 2014; 13:219.

88. Nagel D, Bognar M, Eitelhuber AC, Kutzner K, Vincendeau $\mathrm{M}$ and Krappmann D. Combinatorial BTK and MALT1 inhibition augments killing of CD79 mutant diffuse large B cell lymphoma. Oncotarget. 2015; 6:42232-42242. doi: 10.18632/oncotarget.6273. 